\title{
Influence of surgical resection of hepatocellular carcinoma(HCC) for hematogenous dissemination of HCC cells and its effect on recurrence and metastasis: 3 years prospective study
}

\author{
Y. LIU ${ }^{1, *, \neq}$, Y. R. WANG ${ }^{2, \ddagger}$, G. H. DINGI', T. S. YANG ${ }^{1}$, S. L. JIANG ${ }^{1}$, L. WANG ${ }^{1}$, L. J. XUN ${ }^{1}$, R. M. SONG ${ }^{1}$, Z. S. SONG ${ }^{1}$, B. ZHOU \\ ${ }^{1}$ Shanghai $10^{\text {th }}$ People's Hospital, School of Medicine, Tongji University, 301 Middle Yanchang Road, Shanghai, 200072, China; ${ }^{2}$ Shanghai First \\ People's Hospital Affiliated to Jiaotong University, 85 Wujin Road, Shanghai, 200080, China \\ *Correspondence: yliu6633@aliyun.com \\ ${ }^{*}$ Contributed equally to this work.
}

Received October 20, 2014 / Accepted February 11, 2015

\begin{abstract}
Aims was to study whether hepatal surgery leads to hematogenous dissemination of hepatocellular carcinoma (HCC) cells and determine period of its persistence by nested reverse transcription-polymerase chain reaction (RT-PCR).

Peripheral vein blood (5ml) samples were obtained from 54 HCC patients of $\mathrm{T}_{1} \mathrm{~N}_{0} \mathrm{M}_{0}$ and 6 HCC patients of $\mathrm{T}_{2} \mathrm{~N}_{0} \mathrm{M}_{0}$ stage and 20 patients with liver cavernous hemangioma(LCH) before operation and $48 \mathrm{~h}, 72 \mathrm{~h}$ and 1 week after surgical resection of hepatoma between Janurary $1^{\text {st }}, 2007$ and December 31th, 2010. We detected alpha-fetoprotein (AFP) messenger RNA(mRNA) by nested RT-PCR perioperatively.

AFPmRNA of all 60 cases of HCC patients and 20 cases of LCH were negative before hepatal surgery, 28 of $60 \mathrm{HCC}$ cases became positve at $48 \mathrm{~h}$ after surgery $(46.7 \%), 16$ of $60 \mathrm{HCC}$ cases remained positive at $72 \mathrm{~h}$ postoperatively $(26.7 \%)$, none of 60 HCC patients AFPmRNA was detected at 1 week after hepatal surgery(0.0\%). None of LCH patients were detected AFPmRNA after hepatal surgery(0.0\%). For 28 HCC patients with AFPmRNA positive after hepatal surgery, 4 HCC patients developed intrahepatic tumor recurrences in 1 st year $(4 / 28,14.3 \%), 6$ HCC patients relapsed in the second year(6/28, 21.4\%), 10 HCC patients relapsed in the third year(10/28, 35.7\%). For 32 HCC patients with AFPmRNA negative group postoperation, 5 cases relapsed in 1st year $(5 / 32,15.6 \%), 7$ cases developed intrahepatic tumor recurrences in the second year $(7 / 32,21.9 \%), 11$ cases relasped in the third year $(11 / 32,34.4 \%, P>0.05)$, none of HCC patients occured distal metastasis after surgical resection of hepatoma. None of LCH patients relapsed postoperation within three years.

Hepatal surgery may cause HCC cells spreading into peripheral blood shortly, but it may be not concerning with recurrence or metastasis of HCC.
\end{abstract}

Key words: AFPmRNA, Hepatocellular carcinoma (HCC), Reverse transcription-polymerase chain reaction (RT-PCR)

Hepatocellular carcinoma (HCC) is the third leading cause of cancer mortality worldwide. It often follows cirrhosis caused by viral or alcoholic hepatitis. Prognosis remains very poor, and treatment options are few [1]. Curative surgery and liver transplantation are only available to a small minority of early-stage HCC patients. Other common therapies (including ablative therapies, such as percutaneous ethanol intratumoral injection(PEI), transcatheter arterial chemoembolization (TACE), cryoablation(CA) and radiofrequency ablation (RFA) and Sorafenib) are largely palliative. Treatment is complicated by preexisting cirrhosis, as chemotherapy or resection may not be options in a patient with poor liver reserves.
The early diagnosis of HCC helps in improving the patients' prognosis and in the selection of appropriate treatment protocols. Treatment decisions and prognostic predictions in patients with HCC are commonly based on macroscopic tumor characteristics, detected by imaging studies(tumor size, number, lobar distribution, vascular invasion and extrahepatic metastasis), and by the function quality of the non malignant liver. Although the diagnosis and treatment methods of HCC have been developing over the last 20 years, the recurrence and mortality of HCC is still high. One reason is that patients with HCC in the early state are asympatomatic, and most of them present in the late-stage, advanced, or micrometastasis state [2]. 
Table 1. TNM stage of HCC patients with different clinical parameters

\begin{tabular}{lcccc}
\hline Patient's types & Number of patients & Sex $(\mathrm{M} / \mathrm{F})$ & Age $(\mathrm{Yr})$ & Serum AFP $(\mu \mathrm{g} / \mathrm{L})$ \\
\hline HCC with $\mathrm{T}_{1} \mathrm{~N}_{0} \mathrm{M}_{0}$ & 54 & $48 / 6$ & $53.2 \pm 4.6$ & $85.2 \pm 7.6(20-400)$ \\
HCC with $\mathrm{T}_{2} \mathrm{~N}_{0} \mathrm{M}_{0}$ & 6 & $4 / 2$ & $48.7 \pm 5.3$ & $850.6 \pm 44.5(20-1000)$ \\
$\mathrm{LCH}$ & 20 & $7 / 13$ & $51.2 \pm 5.1$ & $<20(\mathrm{normal} \mathrm{level)}$ \\
\hline
\end{tabular}

HCC has a very poor prognosis, and the majority of cases are detected at advanced stages [3]. Systemic therapies, including chemotherapy, are largely ineffective. Local regional therapy other than resection is largely palliative and includes: PEI, TACE, cryoablation and RFA, et al.

The only hope of long-term survival for patients with HCC is surgical resection or liver transplantation. However, after apparently curative resection, recurrences are common, and they largely account for poor survival rates of only $68.5 \%$ at 1 year and $31.9 \%$ at 5 years after HCC resection, and $>80 \%$ of recurrences are intrahepatic [4-6]. HCC recurrences are presumably caused by the incomplete resection of HCC, leaving behind residual tumor at the site of the resected stump, the presence of undetectable regional micrometastasis, and/ or the dissemination of tumor cells into the bloodstream during surgical manipulation $[7,8]$. It has been conceived that one may infer the presence of circulating HCC cells and hence the potential for metastasis if AFP mRNA are detected in peripheral blood. There has been emerging evidence suggesting that AFPmRNA detection is strongly associated with the presence of metastasis or HCC recurrence, particularly after surgery [8-11].

In the present study, we aimed to assess whether surgical maneuver or resection of HCC could lead to hematogenous dissemination of HCC. The quantity and timing of hepatocytes shedding into the circulation of HCC patients were also monitored by nested RT-PCR before and after surgery.

\section{Patients and methods}

Patients. From Janurary $1^{\text {st }} 2007$ to December 31th, 2010, with informed consent and ethic approval from the Ethics Committee of Tongji University of China, $5 \mathrm{ml}$ peripheral blood samples were collected during preoperative and postoperative periods from $54 \mathrm{HCC}$ patients of $\mathrm{T}_{1} \mathrm{~N}_{0} \mathrm{M}_{0}$ stage, 6 HCC patients from $\mathrm{T}_{2} \mathrm{~N}_{0} \mathrm{M}_{0}$ stage [12] (making sure with AFPmRNA negative preoperatively by RT-PCR) and $20 \mathrm{LCH}$ patients(the diameter of liver hemangioma is below $10 \mathrm{~cm}$ ), whom underwent surgical resection with curative aim(data as Table 1 and Table2 showed). Preoperative blood samples were collected from the patients studied at least $1 \mathrm{~d}$ before surgery. Postoperative blood samples were collected at $48 \mathrm{~h}$, $72 \mathrm{~h}$ and 1 week after HCC resection. The diagnosis of HCC was confirmed histologically on each resected specimen postoperatively and with CT scans or Ultrasonography and blood AFP measurements preoperatively.
Peripheral blood mononuclear cell (PBMCs) isolation and RNA extraction. We use a Ficoll overlay procedure to isolate PBMCs from whole blood. Heparinnized whole blood was centrifuged and the plasma fraction was removed. The cellular fraction was enriched for mononuclear cells or possible tumor cells according to the method described by Komeda [11]. Total cellular RNA was extracted with TRIzol Reagent (Invitrogen) according to manufactory's providing procedure.

Nested RT-PCR and detection of AFPmRNA. The reverse transcription reaction was carried out in $20 \mu \mathrm{l}$ reaction mixture using a first-strand cDNA synthesis kit (Products of Promega Company, USA ) by following the manufacture's instructions. Nested PCR was conducted by adding solution $5 \mu$ l of cDNA to $100 \mu$ of reaction mixture containg $10 \mathrm{mM}$ Tris-HCL (pH 9.0), $50 \mathrm{mM}$ potassium chloride, $4.5 \mathrm{mM}$ magnesium chloride, 250nM dNTP 15p mol of each outer primer (EX-sense and EX-antisense) and 2.5 units of Taq DNA polymerase (Products of Promega Company, USA ). The reaction mixtures were

Table 2. Various clinical parameters of HCC patients

\begin{tabular}{lc}
\hline Clinical parameter & Number of HCC patients \\
\hline Stage of HCC & \\
$\mathrm{T}_{1} \mathrm{~N}_{0} \mathrm{M}_{0}$ & $54(90.0 \%)$ \\
$\mathrm{T}_{2} \mathrm{~N}_{0} \mathrm{M}_{0}$ & $6(10.0 \%))$ \\
Tumor size & \\
$<2 \mathrm{~cm}$ & $54(90.0 \%)$ \\
$<2 \mathrm{~cm}$ & $2(5.0 \%)$ \\
$>2 \mathrm{~cm}$ but $<5 \mathrm{~cm}$ & $2(5.0 \%)$ \\
Serum AFP value & \\
$>400 \mu \mathrm{g}$ & $55(91.7 \%)$ \\
$<400 \mu \mathrm{g}$ & $5(8.3 \%)$ \\
Intrahepatic metastasis & \\
Present & $0(0.0 \%)$ \\
Absent & $60(100.0 \%)$ \\
Portal vein thrombosis & \\
Present & $0(0.0 \%)$ \\
Absent & $60(100.0 \%)$ \\
Distant metastasis & \\
Present & $0(0.0 \%)$ \\
Absent & $60(100 \%)$ \\
HBV infection & $60 / 60(100 \%)$ \\
Hepatic function & \\
Child A & $58(96.7 \%)$ \\
Child B & $2(3.3 \%)$ \\
\hline
\end{tabular}




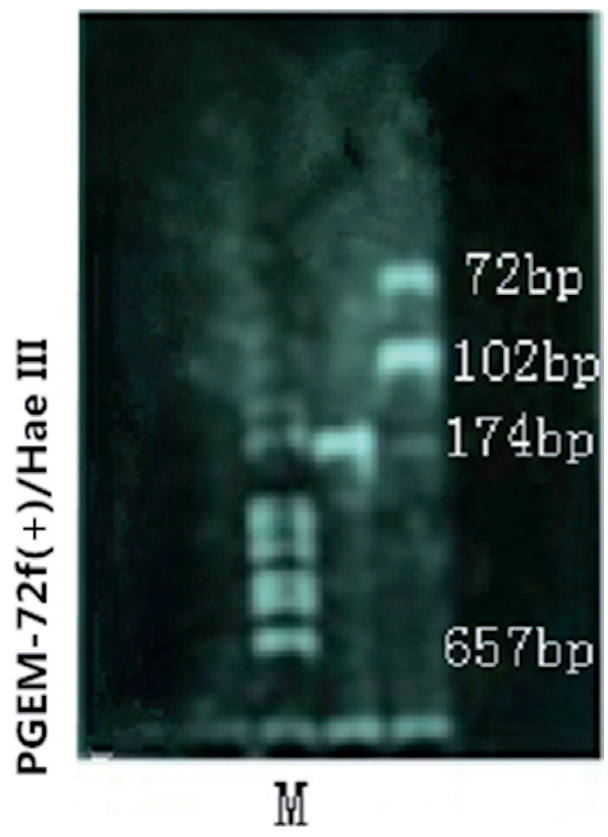

Figure 1. The first products of PCR was cut into two pieces of $102 \mathrm{bp}$ and 72 bp by nuclease PstI.

subjected to 35 cycles of amplification in a programmable thermal cycler (Products of Perkin-Elmer Cetus Corporation, USA ) by using the following sequence : $94^{\circ} \mathrm{C}$ for $1.5 \mathrm{~min}$, $57^{\circ} \mathrm{C}$ for $1.5 \mathrm{~min}$ and $72^{\circ} \mathrm{C}$ for $2.5 \mathrm{~min}$, plus a final extension step at $72^{\circ} \mathrm{C}$ for $10 \mathrm{~min}$. A sample of $10 \mu \mathrm{l}$ of the first amplification product was further amplified using an inner pair of primers( IN-sense and IN-antisense). To verify the amplified AFP DNA fragment, samples were digested with the restriction enzyme Pst I and analysed by electrophoresis on a $2 \%$ agrose gel and stained with ethidium bromide for the specific bands of 174 base pairs ( first amplification product ) and 101 base pairs ( second amplification product ) (11). Nested PCR was conducted two or three times for samples with conflicting results. The designing of external and inner pair of primers as follow:

EX-sense 5'-ACTGAATCCACAACACTGCATAG-3'

EX-antisense 5'-TGCAGTCAATGCATCTTCACCA-3'

IN-sense 5'-TGGAATAGCTTCCATATTGGATTC-3'

IN-antisense 5'-AAGTGGCTTCTTGAACAAACTGG-3'

According to designing of Primer Pairs, the PCR products of 174 and 101 base pairs were amplified from AFPcDNA by external (EX-sense and EX-antisense ) and internal (IN-sense and IN-antisense ) primer pairs, respectively. The primer pairs were located as follow : EX-sense in exon 1 (AFPmRNA nucleotides 90-112), EX-antisense in exon 2 (AFPmRNA nucleotides 263-241), IN-sense over exon 1 and exon 2 (AFPmRNA nucleotides 122-145), IN-antisense in exon 3 (AFPmRNA nucleotides 222-200). cDNA sequences were based upon those previously reported [13]

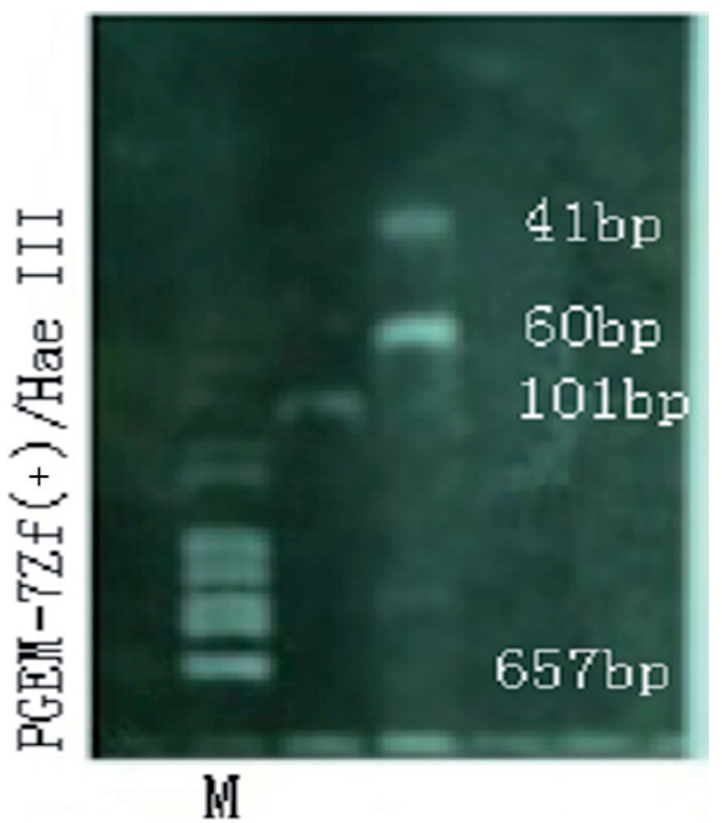

Figure 2. The final products of PCR was cut into two pieces of $60 \mathrm{bp}$ and 41 bp by nuclease Pst I

Differentiation of PCR products. Sodium dodecyl sulfate polyacrylamide gel electrophoresis(SDS-PAGE) was used as analysis. The first cycles products of PCR is 174 base pairs, which can be cut into two pieces of 102 and 72 base pairs by nuclease Pst I. The second cycles products of PCR is 101 base pairs, which can be cut into two pieces of 60 and 41 base pairs by nuclease Pst $I$, shown in Figure 1 and Figure 2.

Patients were followed up at least once every 2 months after surgery by ultrasonography or CT scan, in addition to the measurement of serum a-fetoprotein(AFP). The followup period is 3 years.

Cell lines. We used EDTA-treated water (filtered and vaporized) as a negative control and HepG2 (hepatoblastoma) cell line (Sigma) as a positive control for AFP mRNA expression. HepG2 cells were cultured in RPMI 1640 medium containing $10 \%$ inactived fetal bovine serum in a humidified atmosphere with $5 \% \mathrm{CO}_{2}$ incubator at $37^{\circ} \mathrm{C}$. The sensitivity of our assay, determined in a dilution experiment using freshly isolated human hepatocytes $\left(10^{2}-10^{1}\right)$ in $1 \mathrm{~mL}$ of whole blood before RNA extraction, was approximately 1 hepatoma cell for every $10^{5}$ peripheral mononuclear cells.

Statistical analysis. Results are expressed as mean \pm SD, Fisher's exact test were used to determine differences between groups. $P<0.05$ was considered significant.

\section{Results}

AFPmRNA from clinical sample. AFPmRNA of all 60 cases of HCC patients were negative before surgical resection. 
Table 3. AFPmRNA was detected by RT-PCR before and after sugical resection(SR) in different time

\begin{tabular}{lcccc}
\hline Type of HCC & Before SR & $48 \mathrm{~h}$ after SR & $72 \mathrm{~h}$ after SR & 1 week after SR \\
\hline Number of AFPmRNA(-) & $60(100 \%)$ & $32(53.3 \%)$ & $44(73.3 \%)$ & $60(100 \%)$ \\
Number of AFPmRNA(+) & $0(0 \%)$ & $28(46.7 \%)$ & $16(26.7 \%)$ & $0(0.0 \%)$ \\
\hline
\end{tabular}

Table 4. HCC recurrence with different peroid and different groups

\begin{tabular}{lcc}
\hline Recurrent periods & number of AFPmRNA(+)group & number of AFPmRNA(-)group \\
\hline Number of first year & $4(14.3 \%)$ & $5(15.6 \%)^{*}$ \\
Number of second year & $6(21.4 \%)$ & $7(21.9 \%)^{*}$ \\
Number of third year & $10(35.7 \%)$ & $11(34.4 \%)^{*}$ \\
\hline
\end{tabular}

Fisher's exact test, $P>0.05$

There were 28 patients in 60 HCC patients being detected AFPmRNA in 48 hours after hepatal surgery $(28 / 60,46.7 \%)$, 16 patients with AFPmRNA positive in 72 hours after hepatal surgery (16/60, 26.7\%), all HCC patients with negative AFPmRNA at 1 week after hepatal surgery $(0.0 \%)$, showed in Table 3. None of LCH patients were detected AFPmRNA after hepatal surgery at any time.

Time for recurrence and metastasis. All the HCC patients were followed up for 3 years. For 28 HCC patients with AFPmRNA positive after hepatal surgery, 4 patients developed intrahepatic tumor recurrences within 1 year $(4 / 28,14.3 \%)$, 6 cases relapsed in the second year(6/28, 21.4\%), 10 cases relapsed in the third year(10/28, 35.7\%). For 32 HCC patients with AFPmRNA negative before and after hepatal surgery, 5 cases developed intrahepatic tumor recurrences within 1 year (5/32, 15.6\%), 7 cases developed intrahepatic tumor recurrences within the second year $(7 / 32,21.9 \%), 11$ cases developed intrahepatic tumor recurrences whin the third year $(11 / 32,34.4 \%)$, showed in Table 4, none had lung or distal metastasis. None of LCH patients relapsed postoperation within three years.

\section{Discussion}

Hepatal surgery is the treatment of choice for hepatocellular carcinoma (HCC), but HCC resection is considered to be possible spreading HCC cells into blood circulation via portal blood flow [14]. There have been correlative studies exploring the prognostic factors of HCC recurrence after curative resection $[15,16]$. Among those clinicopathological factors, characteristics representing pathological invasiveness are the most consistent indicator of long-term prognosis. We demonstrated that the presence of circulating HCC cells by assaying a positive AFP mRNA in the peripheral blood within 1 week after curative resection of HCC is not associated with an increased risk of recurrence and a shorter recurrence-free survival.

Reverse-transcriptase polymerase chain reaction (RT-PCR) is a sensitive and versatile method to amplify cDNA gener- ated by reverse transcriptase from mRNA. It is very helpful in the qualification or quantitation of the very small amount of RNA. However, RNA is less robust than DNA. After about 35 cycles of amplification, the yield visualized might not be clear and specific enough. Nested RT-PCR is developed to perform with 1 set of primers (the first round) and then with or without removal of reagents, to reamplify with an internally situated "nested" set of primers (the second round). This process ensures that all products nonspecifically amplified in the first round will not be amplified in the second round, producing a yield that is specific and enhanced. The increased sensitivity and specificity of nested RT-PCR were readily apparent in patients with minimal residual disease.

A higher risk of HCC recurrence has been reported for patients with preoperative circulating AFP mRNA. However, only those who also persistently tested postoperatively positive for circulating AFP mRNA had a higher recurrence rate $[17,18]$.

The HCC tissue is surrounded by a vascular space analogous to the hepatic sinusoids. Because of this anatomic structure, tumor cells might easily be released into the sinusoids after detachment from a tumor focus after either spontaneous or iatrogenic detachment from a tumor, and these cells might migrate into the portal or hepatic vein and finally enter the systemic circulation. Whether micrometastasis occurs is determined by the ability of tumor emboli to survive in the circulation, attach firmly to the endothelium of distant organ capillaries, gain entrance to extravascular tissues, evade host defense mechanisms, and then grow into tumor colonies. Preoperative circulating AFP mRNA in peripheral blood may represent shedding of cells from primary HCC. However, the shedding process should cease after curative resection of HCC. Isolated tumor cells remaining at that time are probably destroyed immunologically. This may explain why preoperative AFP mRNA correlates poorly with tumor recurrence.

Witzigmann et al and Lemoine et al $[19,20]$ did not find any correlation between postresection recurrence of HCC and the presence of circulating AFPmRNA, irrespective of whether it was measured before, during, or after surgery. 
The best timing for postoperative blood sampling is still uncertain. Funaki et al [21] and Okuda et al [17] thought circulating HCC cells transiently liberated during surgery would be destroyed within 7 days.

We analyzed the timing of shedding and lasting time of AFP-expressing HCC cells into the circulation of patients with HCC undergoing surgical resection. Our present data clearly demonstrate that HCC cells are released into the bloodstream during surgery for part of HCC patients, as reflected by the detection of AFPmRNA. The presence of AFPmRNA after surgical resection, implicated the mechanical spillage of HCC cells into the circulation during surgery.

Our findings clearly showed 28 cases of $60 \mathrm{HCC}$ patients were AFPmRNA positive at $48 \mathrm{~h}$ postoperation (46.7\%), 16 HCC patients with AFPmRNA positive at 72 hours after hepatal surgery (26.7\%), all HCC patients with AFPmRNA negative at 1 week after hepatal surgery (0.0\%). The AFPmRNA disappearance may be caused by mechanical kills and immunocytes attack of the body [22]. None of LCH patients were detected AFPmRNA after hepatal surgery at any time $(0.0 \%)$

All the patients were followed up for 3 years. For 28 HCC patients with AFPmRNA positive after hepatal surgery, 4 HCC patients developed intrahepatic tumor recurrences within 1 year $(4 / 28,14.3 \%), 6$ cases relapsed in the second year $(6 / 28$, $21.4 \%), 10$ cases relapsed in the third year(10/28, 35.7\%). For 32 HCC patients with AFPmRNA negative before and after hepatal surgery, 5 cases developed intrahepatic tumor recurrences within 1 year (5/32, 15.6\%), 7 cases developed intrahepatic tumor recurrences within the second year $(7 / 32$, $21.9 \%), 11$ cases developed intrahepatic tumor recurrences whin the third year $(11 / 32,34.4 \%, P>0.05)$, none of HCC patients had lung or distal metastasis. None of LCH patients relapsed postoperation within three years.

We present evidence that AFP-expressing HCC cells are disseminated intraoperatively into the circulation and lasted short period postoperatively(within 1 week). We think surgical resection of HCC may caused HCC cells spreading into peripheral blood shortly, but it is not concerning with recurrence and metastasis of HCC, just as the report from Sheen's [23]. HCC tumor vaccines may also play important role in clearance of these circulating HCC cells which may concern with HCC recurrence or metastasis, the further study is on the way $[24,25,26]$.

Acknowledgements: This research is supported by the grant of National Natural Science Fundation of China (NSFC, No.81372461). We would like to thanks for Xugeng Liu's helping in the process of writing and revising the manuscript.

\section{References}

[1] YANG LIU, YUE-RU WANG, LONG WANG, RUI-MEI SONG, BO ZHOU, et al. Significance of detecting circulating hepatocellular carcinoma cells in peripheral blood of hepatocellular carcinoma patients by nested reverse transcription-polymerase chain reaction and its clinical value. Tumori 2014; 100: 536-540.

[2] TUNCA B, EGELI U, CECENER C, TEZCAN G, TEZCAN G, et al. CK19, CK20, EGFR and HER2 status of circulating tumor cells in patients with breast cancer. Tumori 2012; 98: 243-251.

[3] YANG LIU, YUE-RU WANG, LONG WANG, RUI-MEI SONG, BO ZHOU, et al. Effect of circulating hepatpocellular carcinoma(HCC) cells for HCC recurrence and metastasis after HCC resection: 3 years prospective study. Tumori 2015; 101: (accepted).

[4] JORDI BRUIX and MORRIS SHERMAN. Management of Hepatocellular Carcinoma: An Update. Hepatology 2011; 53: 1020-1022. http://dx.doi.org/10.1002/hep.24199

[5] ANDREW J, PAGE DAVID C, COSGROVE, BENJAMIN PHILOSOPHE, TIMOTHY M. Pawlik. Hepatocellular Carcinoma: Diagnosis, Management, and Prognosis. Surgical Oncology Clinics of North America 2014; 23: 289-311. http:// dx.doi.org/10.1016/j.soc.2013.10.006

[6] KUO-SHYANG JENG, I-SHYAN SHEEN and YI-CHUN TSAI. Does the Presence of Circulating Hepatocellular Carcinoma Cells Indicate a Risk of Recurrence after Resection?Circulating Hepatocellular Carcinoma Cells Indicate a Risk of Recurrence. American Journal of Gastroenterology 2004; 99: 1503-1509. http://dx.doi.org/10.1111/j.1572-0241 $.2004 .30227 . \mathrm{x}$

[7] UMBERTO CILLO, ALESSANDRO VITALE, FILIPPO NAVAGLIA, DANIELA BASSO, UMBERTOMONTIN, et al. Role of blood AFP mRNA and tumor grade in the preoperative prognostic evaluation of patients with hepatocellular carcinoma. World J Gastroenterol 2005; 11: 6920-6925.

[8] ESCHWEGE P, DUMAS F, BLANCHET P, MAIRE V L, BENOIT G, et al. Haematogenous dissemination of prostatic epithelial cells during radical prostatectomy. Lancet 1995; 346: 1528-1530. http://dx.doi.org/10.1016/S0140-6736(95)92054-4

[9] MATSUMURA M, NIWA Y, KATO N, KOMATSU Y, SHIINA S, et al. Detection of $\alpha$-fetoprotein mRNA, an indicator of hematogenous spreading hepatocellular carcinoma, in the circulation: a possible predictor of metastatic hepatocellular carcinoma. Hepatology 1994; 20: 1418-1425. http://dx.doi. org/10.1002/hep.1840200607

[10] NAMBU S, NISHIMORI H, SAEKI M, HIGUCHI K, WATANABE A. Alpha-fetoprotein messenger RNA in peripheral blood as a marker of circulating hepatocellular carcinoma cells. Int. Hepatol. Commun 1995; 3: 217-221. http://dx.doi. org/10.1016/0928-4346(94)00177-7

[11] KOMEDA T, FUKUDA Y, SO T, KITA R, FURUKAWA $M$, et al. Sensitive detection of circulating hepatocellular carcinoma cells in peripheral venous blood. Cancer 1995; 75: 2214-2219. http://dx.doi.org/10.1002/1097-0142(19950501)75:9<2214::AID-CNCR2820750905>3.0.CO;2-X

[12] HERMANEK P, SOBIN LH, EDITORS. UICC TNM Classification of malignant tumors. 4th ed. 2nd rev. Berlin: Springer-Verlag, 1992.

[13] YANG LIU, BAI-HEZHANG, GUANG-XIANG QIAN, HAN CHEN, MENG-CHAO WU. Detection of blood AFPmRNA 
in nude mice bearing human HCC using nested RT-PCR and its significance. World J Gastroenterol 1998; 4: 268-270.

[14] YAMANAKA N, OKAMOTO E, FUJIHARA S, KATO T, FUJIMOTO J, et al. Do the tumor cells of hepatocellular carcinomas dislodge into the portal venous stream during hepatic resection?Cancer 1992; 70: 2263-2267. http:// dx.doi.org/10.1002/1097-0142(19921101)70:9<2263::AIDCNCR2820700909>3.0.CO;2-M

[15] YAMANAKA N, OKAMOTO E, TOYOSAKA A, MITUNOBI M, FUJIHARA S, et al. Prognostic factors after hepatal surgery for hepatocellular carcinoma: a univariate and multivariate analysis. Cancer 1990; 65: 1104-1110. http:// dx.doi.org/10.1002/1097-0142(19900301)65:5<1104::AIDCNCR2820650511>3.0.CO;2-G

[16] ERCOLANI G, GRAZI GL, RAVAIOLI M, GAUDIO MD, GARDINI A, et al. Liver resection for hepatocellular carcinoma on cirrhosis: univariate and multivariate analysis of risk factors for intrahepatic recurrence. Ann Surg 2003; 237: 536-543. http://dx.doi.org/10.1097/01.SLA.0000059988.22416.F2

[17] OKUDA N, NAKAO A, TAKEDA S, OSHIMA K, KANAZUMI N, et al. Clinical significance of alpha fetoprotein mRNA during perioperative period in HCC. Hepatogastroenterology1999; 46: 381-386.

[18] IJICHI M, TAKAYAMA T, MATSUMURA M, SHIRATORI Y, OMATA M, et al. Alpha-fetoprotein mRNA in the circulation as a predictor of postsurgical recurrence of hepatocellular carcinoma: a prospective study. Hepatology 2002; 35: 853-860. http://dx.doi.org/10.1053/jhep.2002.32100

[19] WITZIGMANN H, GEISSLER F, BENEDIX F, THIERY J, UHLMANN D, et al. Prospective evaluation of circulating hepatocytes by alpha-fetoprotein messenger RNA in patients with hepatocellular carcinoma. Surgery 2002; 131: 34-43. http://dx.doi.org/10.1067/msy.2002.118954

[20] LEMOINE A, LE BRICON T, SALVUCCI M, AZOULAY D, PHAM P, et al. Prospective evaluation of circulating hepatocytes by alpha fetoprotein mRNA in humans during liver surgery. Ann Surg 1997; 226: 43-50. http://dx.doi. org/10.1097/00000658-199707000-00006

[21] FUNAKI NO, TANAKA J, SETO SI, KASAMATSU T, KAIDO T, et al. Hematogenous spreading of hepatocellular carcinoma cells: possible participation in recurrence in the liver. Hepatology 1997; 25: 564-568. http://dx.doi. org/10.1002/hep.510250312

[22] KUO-SHYANG JENG, I-SHYAN SHEEN, YI-CHUN TSAI. Circulating messenger RNA of $\alpha$-Fetoprotein: A possible risk factor of recurrence after resection of hepatocellular carcinoma. Arch Surg 2004; 139: 1055-1060. http://dx.doi. org/10.1001/archsurg.139.10.1055

[23] I-SHYAN SHEEN, KUO-SHYANG JENG, SHOU-CHUAN SHIH, PO-CHUAN WANG, WEN-HSIUNG CHANG, et al. Does surgical resection of hepatocellular carcinoma accelerate cancer dissemination? World J Gastroenterol 2004; 10: 31-36.

[24] YANG LIU, SEAN DALEY, VIKTORIA N, EVDOKIMOVA, DAVID D, ZDOBINSKI, DOUGLAS M, POTTER, et al. Hierarchy of alpha Fetoprotein (AFP)-specific T cell responses in subjects with AFP-positive hepatocellular cancer. J Immunol 2006; 177: 712-721. http://dx.doi.org/10.4049/ jimmunol.177.1.712

[25] VIKTORIA N, EVDOKIMOVA, YANG LIU, DOUGLAS M. POTTER and LISA H. BUTTERFIELD. AFP-specific CD4 helper T-cell responses in healthy donor and HCC patients . J Immunother 2007; 30: 425-437. http://dx.doi.org/10.1097/ CJI.0b013e31802fd8e2

[26] YANG LIU, BUTTERFIELD, L H, XIAO-HUI FU, ZHENSHUN SONG, XIAO-PING ZHANG, et al. Lentivirally Engineered DC activate AFP-specific CD8+/CD4+ T cells whcich Inhibit Hepatocellular Carcinoma Growth in vitro and in vivo. International Journal of Oncology 2011; 39: 245-253. 